\title{
Evaluation of PhD Students' and Endodontists' Treatment Approaches during the COVID-19 Pandemic: A Questionnaire-Based Survey
}

\author{
Keziban Olcay ${ }^{1,2, \bullet}$ Selen I. Yusufoglu ${ }^{3}$ \\ ${ }^{1}$ Department of Endodontics, Faculty of Dentistry, Istanbul \\ University-Cerrahpasa, Istanbul, Turkey \\ ${ }^{2}$ Department of Endodontics, Faculty of Dentistry, Istanbul Medipol \\ University, Istanbul, Turkey \\ ${ }^{3}$ Department of Endodontics, Faculty of Dentistry, Ankara Yildirim \\ Beyazit University, Ankara, Turkey \\ Eur Dent Res Biomater J 2021;2:17-27.
}

\begin{abstract}
Address for correspondence Keziban Olcay, DDS, PhD, Kocamustafapaşa Cd. No:34/E, Postal Code:34098 34/E, Department of Endodontics, Faculty of Dentistry, Istanbul University-Cerrahpasa, Cerrahpasa, Fatih, Istanbul (e-mail: kolcay@istanbul.edu.tr).
\end{abstract}

\begin{abstract}
Objectives This study aimed to evaluate endodontists' treatment approaches during the novel coronavirus disease (COVID-19) pandemic.

Materials and Methods Web-based 16-question survey was sent to members of the Turkish Endodontic Society via social media and email between May 5 to 25, 2020, to obtain information about the members' demographic characteristics and treatment approaches of seven cases considering COVID-19. The cases represented different endodontic diseases such as symptomatic apical periodontitis, chronic apical periodontitis, acute apical abscess, asymptomatic and symptomatic cases required retreatment, third molar tooth with endodontic symptoms, and symptomatic irreversible pulpitis.

Statistical Analysis Statistical analysis was performed using a Chi-square test. The statistical significance was set at $\alpha=0.05$.

Results Of the 203 respondents, $65.5 \%$ were females and $34.5 \%$ were males, $62.6 \%$ were endodontists and $37.4 \%$ were $\mathrm{PhD}$ students, $68 \%$ worked at a university, $21.2 \%$ worked at private clinics, and $10.8 \%$ worked at public clinics. Frequency of going to work was mostly once a week (31\%). Most commonly performed treatments were "acute apical abscess (32.2\%)" and "symptomatic irreversible pulpitis (30.8\%)." The

Keywords

- coronavirus

- COVID-19

- endodontics

- pandemic

- survey respondents most frequently preferred "to prescribe antibiotics and/or painkillers and postpone the treatment" in cases 1 and 6, "to follow-up" in cases 2 and 5, "to extract the tooth" in case 4, and "to start endodontic treatment but postpone the treatment by placing antibacterial medicament into the root canals" in cases 3 and $7(p<0.05)$. Conclusion During a pandemic, the general treatment approach for endodontic emergencies should be to eliminate acute symptoms and minimize the risk of transmission.
\end{abstract}

DOI https://doi.org/ 10.1055/s-0041-1727091
(C) 2021. European Dental Research and Biomaterials Journal. This is an open access article published by Thieme under the terms of the Creative Commons Attribution-NonDerivative-NonCommercial-License, permitting copying and reproduction so long as the original work is given appropriate credit. Contents may not be used for commercial purposes, or adapted, remixed, transformed or built upon. (https://creativecommons.org/licenses/by-nc-nd/4.0/).

Thieme Medical and Scientific Publishers Pvt. Ltd. A-12, 2nd Floor, Sector 2, Noida-201301 UP, India 


\section{Introduction}

On December 31, 2019, the World Health Organization (WHO) reported that cases of pneumonia of unknown etiology ${ }^{1}$ occurred in the city of Wuhan, in the Hubei, China province. ${ }^{2}$ The cause of these cases was found to be a new coronavirus (2019-nCoV), which had not been previously detected in humans and the disease was named as the new coronavirus disease (COVID-19), but it was later renamed as severe acute respiratory syndrome-coronavirus-2 (SARS-CoV-2). ${ }^{3}$

The virus is transmitted from person to person mainly through close contact and droplets that infected individuals scatter into the environment through speech, coughing, and sneezing. ${ }^{3}$ The agent is also transmitted to the oral, nasal, and eye mucosa by hand contact with surfaces contaminated with these droplets. ${ }^{4}$ The presence of COVID-19 has been detected in the saliva of infected patients ${ }^{5}$ and can be transmitted directly or indirectly with saliva. ${ }^{6}$ Moreover, many live virus particles have been identified on the epithelial surface of the oral mucosa and on the dorsum of tongue of the SARS-CoV-2-positive patient. ${ }^{7}$

Angiotensin-converting enzyme II (ACE2) is the main host cell receptor of the virus. ACE2 receptors are abundant in oral mucosal tissues, salivary glands, and especially in epithelial cells of the tongue which are considered a potential high risk for the SARS-CoV-2 infection. ${ }^{7}$ ACE2 has also been found on the tongue and mouth. ${ }^{7}$ These receptors are considered to play a target role in the binding of 2019-nCoV and increase susceptibility to infection in individuals. ${ }^{6}$ Additionally, dental professionals are likely to transmit $2019-\mathrm{nCoV}$ due to prolonged face-to-face contact with the patient ${ }^{4}$ and aerosols formed during dental procedures. ${ }^{8}$ Besides, the incubation period of SARS-CoV-2 disease is 5 to 6 days on average, and in some cases, symptoms of the disease are observed after 14 days, ${ }^{4}$ but this period can be extend up to 24 days. ${ }^{9}{ }^{10}$ As many people experience only mild symptoms of the disease $^{11}$ and individuals who have no symptoms can easily transmit the disease, ${ }^{12}$ dental professionals are highly likely to encounter 2019-nCoV and spread the disease.

Among dental professionals, endodontists are highly likely to encounter patients with suspected or diagnosed SARS-CoV-2 infection ${ }^{10}$ because (1) endodontists are the first contact for patients with odontogenic pain and/or swelling, (2) endodontic emergencies receive the majority of dental emergency applications ${ }^{13}$ during the COVID-19 pandemic, ${ }^{14}$ and (3) endodontic treatment is time consuming and thus requires long-term close contact with the patient. The use of air-water sprays and high-speed tools during treatment also causes a considerable amount of aerosol formation. ${ }^{15}$ Since $2019-\mathrm{nCoV}$ can live for at least 3 hours in aerosols and days on surfaces, ${ }^{16}$ SARS-CoV-2 is likely to be transmitted by aerosol transmission. Therefore, endodontic specialists could increase the risk of spreading the infection.

Emergency treatments in endodontics describe conditions that are caused by infection or inflammation of the pulpal and/or periapical tissues, often with severe pain or swelling, and require urgent diagnosis and treatment. These are problematic situations that create some special difficulties for both the specialist and the patient in diagnosis and treatment approach. Endodontists employed different treatment approaches for patients who applied for emergency treatment in endodontics during the pandemic period. Therefore, this questionnaire-based survey identifies the treatment approaches used and contributes to a consensus on the endodontic treatment procedures and the patient management protocol to apply during the COVID-19 pandemic.

\section{Materials and Methods}

Ethical approval of the study design was obtained from the institutional review board of Istanbul Medipol University (approval number:10840098-604.01.01-E.14696/326) and Ministry of Health of Turkey. Verbal consent was obtained from the patients whose radiographs were used for reference in the study. In this survey, the participants were only given information about the patients in accordance with the clinical scenarios and radiographs provided for reference. Only the principal researcher had access to the data. Participation in the study was voluntary, and the questionnaires were anonymous to ensure the privacy of all information obtained from the study.

\section{Sample Size Calculation}

There are in total $704 \mathrm{PhD}$ students and endodontists in endodontic departments registered with the Turkish Endodontics Association. Therefore, the population size of the study group was 704 . The confidence level of the research was calculated as 95\% and confidence interval (margin of error) was 5.81 with the power analysis. The sample size was calculated as 203 participants, representing 90\% power. When the number of participants reached 203, the survey was completed.

\section{Design of the Survey and Data Collection}

An online 16-question survey (available at: https://docs. google.com/forms/d/e/1FAIpQLScW4E87E1yaDvN54ec3zA_ KkqUjBuOzawCHclOOypooz_8h2w/viewform?usp=pp_url) and a brief cover letter describing the study was formulated using Google forms. The survey data were collected during a 3-week period from May 5 to 25, 2020. The estimated completion time for the questionnaire was 3 to 4 minutes. A list of current members of the Turkish Endodontic Society was obtained from its web site, and a link to the survey was sent via social media (Instagram) and e-mail to all members. Of the 620 people the survey reached, 203 responded to the questionnaire.

The participants were asked to record the following:

- Demographic data (gender, age, professional experience, education level, and place of work).

- Information about COVID-19 (frequency of going to work, the endodontic diseases treated, and the preferred methods of communication with patients during the COVID-19 pandemic). 
- Treatment approaches the respondents would apply to seven cases selected among patients who presented to the Department of Endodontics, Faculty of Dentistry, Istanbul Medipol University, between March 16 and April 23, 2020.

All clinical cases were structured as multiple-choice questions, and each participant was requested to choose only one treatment option for each case. However, participants were able to select more than one option to answer the following questions: "Which of the following diseases did you treat during the COVID-19 pandemic?" and "How do you communicate with the patients during the COVID-19 pandemic?" The respondents could choose from the following seven treatment options:

1. Prescribe antibiotics and/or painkillers and postpone treatment.

2. Start endodontic treatment but postpone full treatment by removing coronal pulp tissue only.

3. Start endodontic treatment but postpone full treatment by placing a material-like devitalizing/eugenol liquid on the pulp.

4. Start endodontic treatment but postpone full treatment by placing antibacterial medicament into the root canals.

5. Start endodontic treatment and complete all treatment procedures.

6. Tooth extraction.

7. Follow-up.

The participants were asked to select a treatment approach for the following seven cases, considering their current situation during the COVID-19 outbreak:

Case 1 (symptomatic apical periodontitis): A 51-year-old systemically healthy female patient presents with a complaint of severe pain lasting for a week in the left mandibular molar region. The patient received fixed prosthetic restoration on the painful area a few months prior. There is no periapical swelling. What is your treatment approach for tooth 37 ? (-Fig. 1A).

Case 2 (chronic apical periodontitis): A 74-year-old systemically healthy male patient presents with a fall in a 25-year bridge in the maxillary anterior region. All teeth under the bridge are devastated to the cementoenamel junction but there is no pain or swelling. What is your treatment approach for tooth 21? (-Fig. 1B).

Case 3 (acute apical abscess): A 17-year-old systemically healthy male patient presents with a complaint of severe pain lasting five days in the right mandibular molar region. Tooth 46 has profound caries with positive percussion and palpation. There is intraoral swelling in the apical of tooth 46 . What is your treatment approach for tooth 46 ? (-Fig. 1C).

Case 4 (third molar tooth with endodontic symptoms): A 40-year-old systemically healthy female patient presents with a complaint of severe pain for 3 days in the upper right molar region. Severe percussion sensitivity is present in teeth 17 and 18 . There is no caries on tooth 17 . On tooth 18 , there is a profound caries on the buccal surface, palpation is negative, and there is no intraoral swelling. What is your treatment approach for tooth 18 ? ( - Fig. 1D).

Case 5 (asymptomatic case required retreatment): A 22-year-old systemically healthy female patient presents with a fracture in the right mandibular molar region. The patient received root canal treatment of tooth 46, 3 years ago, and there is a limited fracture in the coronal restoration. The patient has no discomfort other than sensitivity observed occasionally during chewing. Percussion and palpations are negative, and there is no swelling. What is your treatment approach for tooth 46? (- Fig. 1D).

Case 6 (symptomatic case required retreatment): A 55-year-old systemically healthy male patient presents

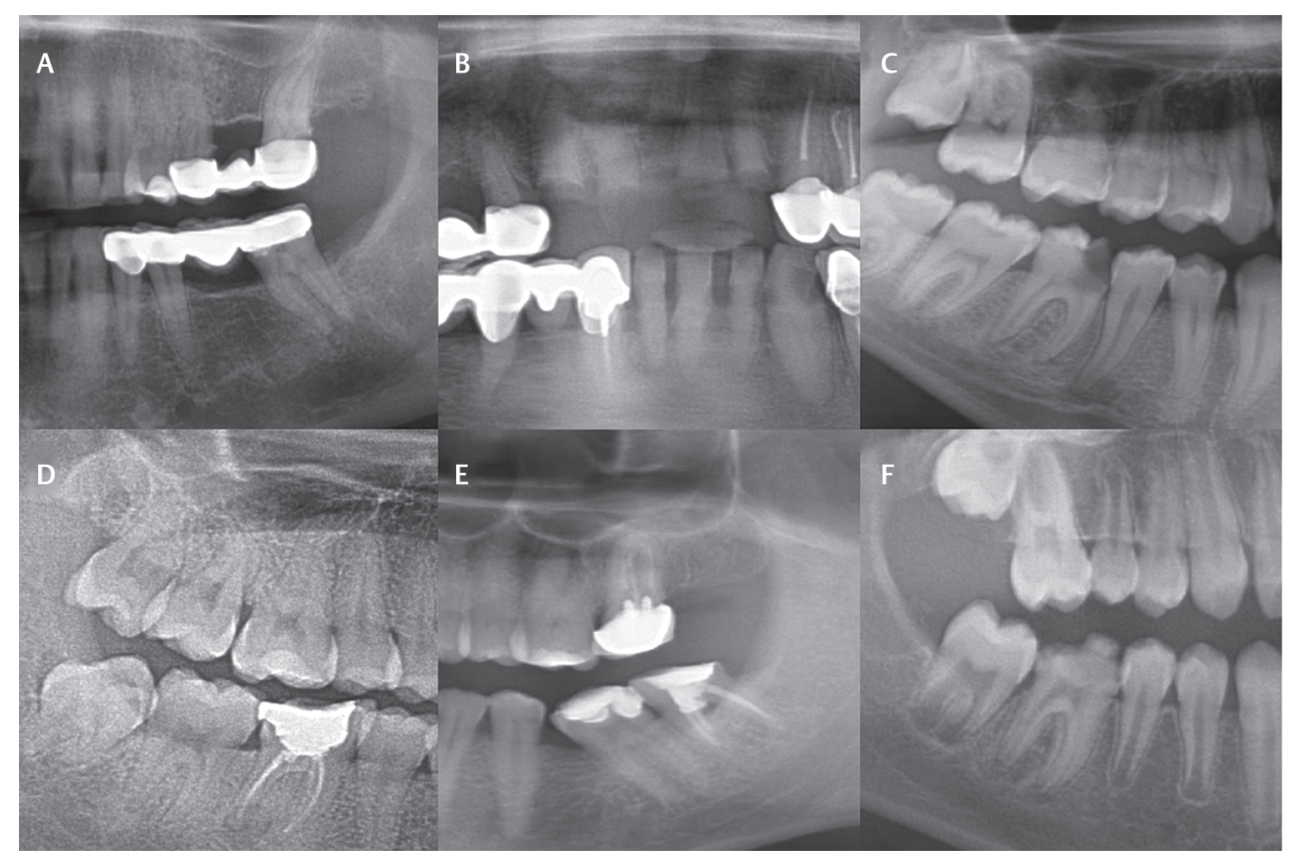

Fig. 1 Radiographies of the cases in the survey. (A) Radiography of case 1. (B) Radiography of case 2. (C) Radiography of case 3. (D) Radiography of cases 4 and 5. (E) Radiography of case 6. (F) Radiography of case 7. 
with severe pain in the maxillary left molar region. The patient received root canal treatment of tooth 27, 5 years ago. Tooth 27 has severe percussion sensitivity, palpation is negative, and there is no swelling. What is your treatment approach for tooth 27 ? ( - Fig. 1E).

Case 7 (symptomatic irreversible pulpitis): A 10-year-old systemically healthy male patient presents with severe pain in the lower right molar region. Tooth 46 has severe percussion sensitivity, and there is a long-term complaint of severe pain that begins spontaneously. There is no swelling. What is your treatment approach for tooth 46 ? (-Fig. 1F).

\section{Statistical Analysis}

The obtained data were exported as a Microsoft Excel (2007) spreadsheet (Microsoft Office, Redmond, California, United States). Statistical evaluation was performed using SPSS statistical software program (version 22.0, SPSS Inc., Chicago, Illinois, United States). Descriptive statistics (frequencies) were calculated for all the recorded variables for each group. Differences of the measured variables were assessed using a Chi-square test. A $p$-value of $<0.05$ was considered significant for all tests.

\section{Results}

A total of $203 \mathrm{PhD}$ students and endodontists participated in the present study, giving a response rate of $28.8 \%$. All participants completed the questionnaires, and there were no missing answers. Of the participants, $65.5 \%$ were females ( $n=133$ ) and $34.5 \%$ were males $(n=70)$. Most of the participants were aged 31 to 40 years $(45.3 \%, n=92)$, followed by 20 to 30 years $(41.4 \%, n=84), 41$ to 50 years $(9.9 \%, n=20)$, and 51 to 60 years $(3.0 \%, n=6)$; only one participant was aged over $61(0.5 \%)$. While $34 \%$ of the participants had less than 5 years' experience ( $n=69), 44.3 \%$ had 6 to 15 years $(n=90), 16.3 \%$ had 16 to 25 years $(n=33)$, and $5.4 \%$ had more than 25 years of experience $(n=11)$. Of the participants, $62.6 \%$ were endodontists ( $n=127$ ), and $37.4 \%$ were PhD students in endodontics $(n=76)$. Among the respondents, $68 \%$ worked at university clinics ( $n=138), 21.2 \%$ at private clinics $(n=43)$, and $10.8 \%$ at public clinics $(n=22)$. While $23.2 \%$ of the participants stated that they did not go to the clinic/hospital during the pandemic period ( $n=47), 7.9 \%$ went once a month $(n=16), 22.2 \%$ went twice a month $(n=45), 31 \%$ went once a week $(n=63)$, $13.3 \%$ went twice a week or more $(n=27)$, and $2.5 \%$ stated that they went to the clinic every day $(n=5)$. During the COVID-19 pandemic, the participants reported that $82.3 \%$ of treated cases were acute apical abscess ( $n=167), 78.8 \%$ were symptomatic irreversible pulpitis $(n=160)$, and $68.5 \%$ were symptomatic apical periodontitis ( $n=139$; - Table 1). To communicate with their patients, $58.1 \%$ stated that they were face to face $(n=118), 55.2 \%$ were by phone $(n=112)$, $10.8 \%$ were via social media $(n=22)$, and $3.9 \%$ used video conferencing $(n=8)$.

For case $1,42.4 \%$ of the participants chose to prescribe antibiotics and/or painkillers and postpone the treatment ( $n=86$ ), followed by $23.6 \%$, who opted to start endodontic treatment but postpone the treatment by placing the anti-

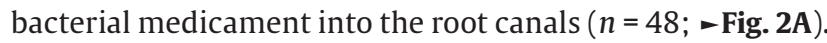
For case 2, 48.3\% preferred to follow-up with the patient ( $n=98$ ) and $16.7 \%$ opted to prescribe antibiotics and/or painkillers and postpone the treatment $(n=34$; - Fig. 2B). For case 3, 48.8\% chose to start endodontic treatment but postpone the treatment by placing the antibacterial medicament into the root canals ( $n=99$ ), and $24.6 \%$ preferred to prescribe antibiotics and/or painkillers and postpone treatment ( $n=50$; - Fig. 2C). For case $4,54.7 \%$ preferred tooth extraction ( $n=111$ ), followed by $22.2 \%$, who opted to prescribe antibiotics and/or painkillers and postpone the treatment ( $n=45$; - Fig. 2D). For case $5,65.5 \%$ decided to follow-up ( $n=133$ ), and $15.8 \%$ opted to prescribe antibiotics and/or painkillers and postpone the treatment ( $n=32$; -Fig. 2E). For case 6, 38.4\% chose to prescribe antibiotics and/or painkillers and postpone the treatment $(n=78)$, and $21.7 \%$ preferred to extract the tooth $(n=44 ;-$ Fig. 2 F). For case $7,38.9 \%$ preferred to start endodontic treatment but postpone the treatment by placing the medicament into the root canals ( $n=79$ ), and $15.3 \%$ preferred to start endodontic treatment and complete the treatment procedures $(n=31 ;$ - Fig. 2G).

Table 1 Information about the diseases treated by the participants during the COVID-19 pandemic

\begin{tabular}{|l|l|l|l|l|}
\hline \multicolumn{2}{|c|}{} & \multicolumn{2}{|c|}{ Responses } & \multirow{2}{*}{ Cases (\%) } \\
\cline { 3 - 5 } \multicolumn{2}{|c|}{$\begin{array}{l}\text { “Which of the following dis- } \\
\text { eases did you treat during the } \\
\text { COVID-19 pandemic?" }\end{array}$} & Reversible pulpitis & 21 & Percentage \\
\cline { 2 - 5 } & Symptomatic irreversible pulpitis & 160 & 30.83 & 10.34 \\
\cline { 2 - 5 } & Asymptomatic apical periodontitis & 7 & 1.35 & 78,82 \\
\cline { 2 - 5 } & Symptomatic apical periodontitis & 139 & 26.78 & 3.45 \\
\cline { 2 - 5 } & Chronic apical abscess & 8 & 1.54 & 68.47 \\
\cline { 2 - 5 } & Acute apical abscess & 167 & 32.18 & 82.27 \\
\cline { 2 - 5 } & Retreatment & 15 & 2.89 & 7.39 \\
\cline { 2 - 5 } & Regenerative endodontic treatment & 2 & 0.39 & 0.99 \\
\hline \multirow{2}{*}{ Total } & & 519 & 100.00 & 242.36 \\
\hline
\end{tabular}

Abbreviation: COVID-19, novel coronavirus disease 2019. 
A statistically significant difference was found between the female and male participants about treatment approaches for cases $1,3,6$, and 7 ( $p<0.05$; - Table 2). For cases 1 and 6 , female participants mostly chose to prescribe antibiotics and/or painkillers and postpone the treatment; and for case 7, female participants preferred to start endodontic treatment but postpone the treatment by placing the antibacterial medicament into the root canals $(p<0.05)$. For case 3, male participants preferred to start endodontic treatment but postpone the treatment by placing the antibacterial medicament into the root canals $(p<0.05)$.

A statistically significant difference was observed between the age groups regarding the treatment approaches selected for cases 1,2 , and $4(p<0.05$;
- Table 3). For case 1, age groups preferred to prescribe antibiotics and/or painkillers and postpone the treatment $(p<0.05)$. For case 2, follow-up was the most common treatment approach for participants in the 20 to 30 and 31 to 40 years of age groups $(p<0.05)$. However, those in the 41 to 50 years of age group opted to prescribe antibiotics and/or painkillers and postpone treatment or follow-up equally for case 2 , showing a significant difference from the other options $(p<0.05)$. For case 4 , all age groups preferred tooth extraction as the most common treatment approach $(p<0.05)$.

Regarding professional experience, all experience levels opted to follow-up with the patient in case 2 , showing a statistically significant difference $(p<0.05$; - Table 4$)$.
A

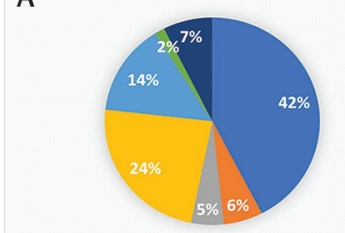

$\mathrm{E}$

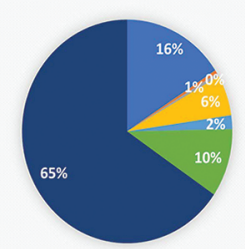

B

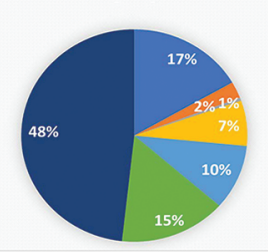

$\mathbf{F}$

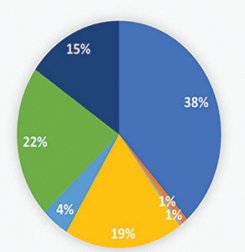

C

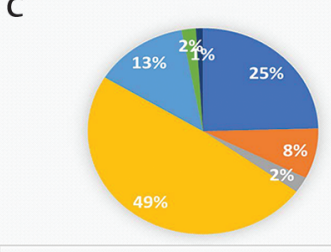

G

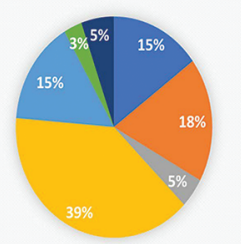

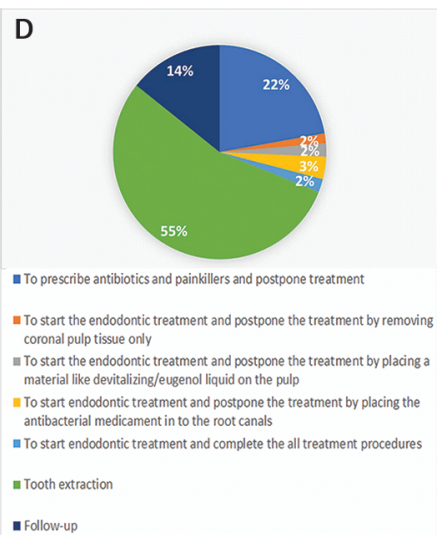

Fig. 2 Graphs showing the distribution of participants' treatment approaches for the cases in the survey. (A) Graph showing results of case 1. (B) Graph showing results of case 2. (C) Graph showing results of case 3. (D) Graph showing results of case 4. (E) Graph showing results of case 5. (F) Graph showing results of case 6. (G) Graph showing results of case 7. Blue: To prescribe antibiotics and painkillers and postpone treatment; Orange: To start the endodontic treatment and postpone the treatment by removing coronal pulp tissue only; Grey: To start the endodontic treatment and postpone the treatment by placing a material like devitalizing / eugenol liquid on the pulp; Yellow: To start endodontic treatment and postpone the treatment by placing the antibacterial medicament in to the root canals; Light Blue: To start endodontic treatment and complete the all treatment procedures; Green: Tooth extraction; Navy Blue: Follow-up.

Table 2 Distribution of participants' responses to cases by gender

\begin{tabular}{|c|c|c|c|c|c|c|c|c|c|c|}
\hline & & $1(\%)$ & $2(\%)$ & $3(\%)$ & $4(\%)$ & $5(\%)$ & $6(\%)$ & $7(\%)$ & $\chi 2^{b}$ & $p$-Value \\
\hline \multirow[t]{2}{*}{ Case 1} & Female & 49.6 & 5.3 & 6.8 & 20.3 & 11.3 & 0.0 & 6.8 & \multirow[t]{2}{*}{17.894} & \multirow[t]{2}{*}{$0.007^{a}$} \\
\hline & Male & 28.6 & 7.1 & 1.4 & 30.0 & 20.0 & 4.3 & 8.6 & & \\
\hline \multirow[t]{2}{*}{ Case 2} & Female & 17.3 & 1.5 & 0.8 & 6.0 & 7.5 & 13.5 & 53.4 & \multirow[t]{2}{*}{7.448} & \multirow[t]{2}{*}{0.281} \\
\hline & Male & 15.7 & 4.3 & 0.0 & 8.6 & 14.3 & 18.6 & 38.6 & & \\
\hline \multirow[t]{2}{*}{ Case 3} & Female & 30.1 & 7.5 & 3.0 & 47.4 & 9.8 & 0.8 & 1.5 & \multirow[t]{2}{*}{12.89} & \multirow[t]{2}{*}{$0.045^{\mathrm{a}}$} \\
\hline & Male & 14.3 & 8.6 & 1.4 & 51.4 & 20.0 & 4.3 & 0.0 & & \\
\hline \multirow[t]{2}{*}{ Case4 } & Female & 24.1 & 0.8 & 2.3 & 3.8 & 0.8 & 56.4 & 12.0 & \multirow[t]{2}{*}{6.753} & \multirow[t]{2}{*}{0.344} \\
\hline & Male & 18.6 & 2.9 & 1.4 & 2.9 & 4.3 & 51.4 & 18.6 & & \\
\hline \multirow[t]{2}{*}{ Case 5} & Female & 19.5 & 0.8 & 0.8 & 4.5 & 1.5 & 9.0 & 63.9 & \multirow[t]{2}{*}{6.685} & \multirow[t]{2}{*}{0.351} \\
\hline & Male & 8.6 & 0.0 & 0.0 & 8.6 & 2.9 & 11.4 & 68.6 & & \\
\hline \multirow[t]{2}{*}{ Case 6} & Female & 44.4 & 0.0 & 0.8 & 16.5 & 1.5 & 21.8 & 15.0 & \multirow[t]{2}{*}{16.326} & \multirow[t]{2}{*}{$0.012^{\mathrm{a}}$} \\
\hline & Male & 27.1 & 2.9 & 0.0 & 22.9 & 10.0 & 21.4 & 15.7 & & \\
\hline \multirow[t]{2}{*}{ Case 7} & Female & 16.5 & 20.3 & 4.5 & 42.9 & 8.3 & 3.0 & 4.5 & \multirow[t]{2}{*}{16.233} & \multirow[t]{2}{*}{$0.013^{\mathrm{a}}$} \\
\hline & Male & 11.4 & 14.3 & 4.3 & 31.4 & 28.6 & 2.9 & 7.1 & & \\
\hline
\end{tabular}

${ }^{\mathrm{a}} \mathrm{p}<0.05$.

${ }^{b}$ Chi-square test. (1) To prescribe antibiotics and painkillers and postpone treatment; (2) to start the endodontic treatment and postpone the treatment by removing coronal pulp tissue only; (3) to start the endodontic treatment and postpone the treatment by placing a material like devitalizing/eugenol liquid on the pulp; (4) to start endodontic treatment and postpone the treatment by placing the antibacterial medicament in to the root canals; (5) to start endodontic treatment and complete the all treatment procedures; (6) tooth extraction; (7) follow-up. 
Table 3 Distribution of participants' responses to cases by age groups

\begin{tabular}{|c|c|c|c|c|c|c|c|c|c|c|}
\hline \multicolumn{2}{|c|}{ Case and age (y) } & $1(\%)$ & $2(\%)$ & $3(\%)$ & $4(\%)$ & $5(\%)$ & $6(\%)$ & 7 (\%) & $\chi 2^{b}$ & $p$-Value \\
\hline \multirow[t]{4}{*}{ Case 1} & $20-30$ & 44.0 & 2.4 & 8.3 & 23.8 & 7.1 & 3.6 & 10.7 & \multirow[t]{4}{*}{33.058} & \multirow[t]{4}{*}{$0.016^{\mathrm{a}}$} \\
\hline & $31-40$ & 38.0 & 6.5 & 2.2 & 25.0 & 22.8 & 0.0 & 5.4 & & \\
\hline & $41-50$ & 55.0 & 20.0 & 0.0 & 20.0 & 5.0 & 0.0 & 0.0 & & \\
\hline & $50+$ & 42.9 & 0.0 & 14.3 & 14.3 & 14.3 & 0.0 & 14.3 & & \\
\hline \multirow[t]{4}{*}{ Case 2} & $20-30$ & 16.7 & 2.4 & 0.0 & 7.1 & 7.1 & 17.9 & 48.8 & \multirow[t]{4}{*}{45.632} & \multirow[t]{4}{*}{$0.001^{\mathrm{a}}$} \\
\hline & $31-40$ & 15.2 & 2.2 & 0.0 & 6.5 & 9.8 & 13.0 & 53.3 & & \\
\hline & $41-50$ & 30.0 & 5.0 & 0.0 & 5.0 & 10.0 & 20.0 & 30.0 & & \\
\hline & $50+$ & 0.0 & 0.0 & 14.3 & 14.3 & 42.9 & 0.0 & 28.6 & & \\
\hline \multirow[t]{4}{*}{ Case 3} & $20-30$ & 21.4 & 10.7 & 3.6 & 51.2 & 8.3 & 2.4 & 2.4 & \multirow[t]{4}{*}{18.01} & \multirow[t]{4}{*}{0.455} \\
\hline & $31-40$ & 28.3 & 5.4 & 1.1 & 48.9 & 15.2 & 1.1 & 0.0 & & \\
\hline & $41-50$ & 30.0 & 5.0 & 5.0 & 40.0 & 15.0 & 5.0 & 0.0 & & \\
\hline & $50+$ & 0.0 & 14.3 & 0.0 & 42.9 & 42.9 & 0.0 & 0.0 & & \\
\hline \multirow[t]{4}{*}{ Case 4} & $20-30$ & 16.7 & 0.0 & 2.4 & 1.2 & 0.0 & 66.7 & 13.1 & \multirow[t]{4}{*}{31.266} & \multirow[t]{4}{*}{$0.027^{a}$} \\
\hline & $31-40$ & 27.2 & 1.1 & 2.2 & 3.3 & 3.3 & 46.7 & 16.3 & & \\
\hline & $41-50$ & 25.0 & 5.0 & 0.0 & 15.0 & 5.0 & 40.0 & 10.0 & & \\
\hline & $50+$ & 14.3 & 14.3 & 0.0 & 0.0 & 0.0 & 57.1 & 14.3 & & \\
\hline \multirow[t]{4}{*}{ Case 5} & $20-30$ & 15.5 & 1.2 & 0.0 & 6.0 & 2.4 & 7.1 & 67.9 & \multirow[t]{4}{*}{15.618} & \multirow[t]{4}{*}{0.619} \\
\hline & $31-40$ & 15.2 & 0.0 & 1.1 & 7.6 & 0.0 & 13.0 & 63.0 & & \\
\hline & $41-50$ & 20.0 & 0.0 & 0.0 & 0.0 & 5.0 & 5.0 & 70.0 & & \\
\hline & $50+$ & 14.3 & 0.0 & 0.0 & 0.0 & 14.3 & 14.3 & 57.1 & & \\
\hline \multirow[t]{4}{*}{ Case 6} & $20-30$ & 35.7 & 2.4 & 1.2 & \begin{tabular}{|l|}
17.9 \\
\end{tabular} & 2.4 & 19.0 & 21.4 & \multirow[t]{4}{*}{14.223} & \multirow[t]{4}{*}{0.714} \\
\hline & $31-40$ & 41.3 & 0.0 & 0.0 & 19.6 & 5.4 & 21.7 & 12.0 & & \\
\hline & $41-50$ & 45.0 & 0.0 & 0.0 & 15.0 & 5.0 & 30.0 & 5.0 & & \\
\hline & $50+$ & 14.3 & 0.0 & 0.0 & 28.6 & 14.3 & 28.6 & 14.3 & & \\
\hline \multirow[t]{4}{*}{ Case 7} & $20-30$ & 15.5 & 20.2 & 7.1 & 34.5 & 11.9 & 2.4 & 8.3 & \multirow[t]{4}{*}{14.765} & \multirow[t]{4}{*}{0.678} \\
\hline & $31-40$ & 14.1 & 15.2 & 3.3 & 41.3 & 18.5 & 3.3 & 4.3 & & \\
\hline & $41-50$ & 20.0 & 15.0 & 0.0 & 40.0 & 20.0 & 5.0 & 0.0 & & \\
\hline & $50+$ & 0.0 & 42.9 & 0.0 & 57.1 & 0.0 & 0.0 & 0.0 & & \\
\hline
\end{tabular}

${ }^{\mathrm{a}} \mathrm{p}<0.05$.

${ }^{b}$ Chi-square test. (1) To prescribe antibiotics and painkillers and postpone treatment; (2) to start the endodontic treatment and postpone the treatment by removing coronal pulp tissue only; (3) to start the endodontic treatment and postpone the treatment by placing a material like devitalizing/eugenol liquid on the pulp; (4) to start endodontic treatment and postpone the treatment by placing the antibacterial medicament in to the root canals; (5) to start endodontic treatment and complete the all treatment procedures; (6) tooth extraction; (7) follow-up.

In terms of education level, both endodontists and PhD students most frequently chose to prescribe antibiotics and/or painkillers and postpone treatment for case 1 , showing a statistically significant difference $(p<$ 0.05; - Table 5).

For cases 1, 3, 5, and 7, a significant difference was found regarding participants' place of work ( $p<0.05$; - Table 6). For case 1, participants working at a university and at public clinics chose most commonly to prescribe antibiotics and/or painkillers and postpone treatment, while participants working in the private sector chose to start endodontic treatment and complete all the treatment procedures $(p<0.05)$. However, for cases 3 and 7 , all groups preferred to start endodontic treatment but postpone the treatment by placing the antibacterial medicament into the root canals, and for case 5, follow-up was the most common treatment approach with a significant difference $(p<0.05)$.

\section{Discussion}

As in many countries worldwide, the spread of COVID-19 has increased in Turkey. ${ }^{17}$ Studies to develop an effective drug and vaccine specific to 2019-nCOV are continuing rapidly all over the world. Since the beginning of the pandemic, important steps have been taken in this regard. With the start of the normalization process, dentists have started to accept patients again to supply the increasing need for dental health services. ${ }^{18}$ Therefore, considering that the incubation period of the disease may extend up to 24 days, ${ }^{9,10}$ it may be inevitable to provide services in the same environment for patients with and without COVID-19. 
Table 4 Distribution of participants' responses to cases by professional experience

\begin{tabular}{|c|c|c|c|c|c|c|c|c|c|c|}
\hline \multicolumn{2}{|c|}{ Case and age (y) } & $1(\%)$ & $2(\%)$ & $3(\%)$ & $4(\%)$ & $5(\%)$ & $6(\%)$ & 7 (\%) & $\chi 2^{b}$ & $p$-Value \\
\hline \multirow[t]{4}{*}{ Case 1} & $<5$ & 43.5 & 2.9 & 10.1 & 24.6 & 4.3 & 2.9 & 11.6 & \multirow[t]{4}{*}{24.051} & \multirow[t]{4}{*}{0.152} \\
\hline & $6-15$ & 42.2 & 6.7 & 2.2 & 23.3 & 20.0 & 1.1 & 4.4 & & \\
\hline & $16-25$ & 42.4 & 12.1 & 0.0 & 24.2 & 15.2 & 0.0 & 6.1 & & \\
\hline & $>25$ & 36.4 & 0.0 & 9.1 & 18.2 & 27.3 & 0.0 & 9.1 & & \\
\hline \multirow[t]{4}{*}{ Case 2} & $<5$ & 18.8 & 2.9 & 0.0 & 7.2 & 5.8 & 18.8 & 46.4 & \multirow[t]{4}{*}{34.214} & \multirow[t]{4}{*}{$0.012^{\mathrm{a}}$} \\
\hline & $6-15$ & 14.4 & 2.2 & 0.0 & 5.6 & 10.0 & 14.4 & 53.3 & & \\
\hline & $16-25$ & 24.2 & 3.0 & 0.0 & 9.1 & 9.1 & 15.2 & 39.4 & & \\
\hline & $>25$ & 0.0 & 0.0 & 9.1 & 9.1 & 36.4 & 0.0 & 45.5 & & \\
\hline \multirow[t]{4}{*}{ Case 3} & $<5$ & 21.7 & 13.0 & 4.3 & 50.7 & 5.8 & 1.4 & 2.9 & \multirow[t]{4}{*}{23.498} & \multirow[t]{4}{*}{0.172} \\
\hline & $6-15$ & 30.0 & 3.3 & 1.1 & 46.7 & 16.7 & 2.2 & 0.0 & & \\
\hline & $16-25$ & 24.2 & 9.1 & 3.0 & 48.5 & 12.1 & 3.0 & 0.0 & & \\
\hline & $>25$ & 0.0 & 9.1 & 0.0 & 54.5 & 36.4 & 0.0 & 0.0 & & \\
\hline \multirow[t]{4}{*}{ Case 4} & $<5$ & 15.9 & 0.0 & 4.3 & 0.0 & 0.0 & 68.1 & 11.6 & \multirow[t]{4}{*}{25.113} & \multirow[t]{4}{*}{0.122} \\
\hline & $6-15$ & 26.7 & 1.1 & 1.1 & 3.3 & 3.3 & 48.9 & 15.6 & & \\
\hline & $16-25$ & 24.2 & 3.0 & 0.0 & 9.1 & 3.0 & 42.4 & 18.2 & & \\
\hline & $>25$ & 18.2 & 9.1 & 0.0 & 9.1 & 0.0 & 54.5 & 9.1 & & \\
\hline \multirow[t]{4}{*}{ Case 5} & $<5$ & 18.8 & 1.4 & 0.0 & 5.8 & 0.0 & 5.8 & 68.1 & \multirow[t]{4}{*}{25.317} & \multirow[t]{4}{*}{0.116} \\
\hline & $6-15$ & 15.6 & 0.0 & 1.1 & 7.8 & 1.1 & 12.2 & 62.2 & & \\
\hline & $16-25$ & 9.1 & 0.0 & 0.0 & 3.0 .0 & 3.0 & 12.1 & 72.7 & & \\
\hline & $>25$ & 18.2 & 0.0 & 0.0 & 0.0 & 18.2 & 9.1 & 54.5 & & \\
\hline \multirow[t]{4}{*}{ Case 6} & $<5$ & 40.6 & 2.9 & 1.4 & 17.4 & 0.0 & 15.9 & 21.7 & \multirow[t]{4}{*}{27.65} & \multirow[t]{4}{*}{0.068} \\
\hline & $6-15$ & 38.9 & 0.0 & 0.0 & 21.1 & 7.8 & 20.0 & 12.2 & & \\
\hline & $16-25$ & 39.4 & 0.0 & 0.0 & 12.1 & 0.0 & 36.4 & 12.1 & & \\
\hline & $>25$ & 18.2 & 0.0 & 0.0 & 27.3 & 18.2 & 27.3 & 9.1 & & \\
\hline \multirow[t]{4}{*}{ Case 7} & $<5$ & 17.4 & 21.7 & 8.7 & 36.2 & 7.2 & 1.4 & 7.2 & \multirow[t]{4}{*}{21.35} & \multirow[t]{4}{*}{0.262} \\
\hline & $6-15$ & 14.4 & 15.6 & 3.3 & 35.6 & 23.3 & 3.3 & 4.4 & & \\
\hline & $16-25$ & 15.2 & 15.2 & 0.0 & 45.5 & 12.1 & 6.1 & 6.1 & & \\
\hline & $>25$ & 0.0 & 27.3 & 0.0 & 63.6 & 9.1 & 0.0 & 0.0 & & \\
\hline
\end{tabular}

a $p<0.05$.

${ }^{b}$ Chi-square test. (1) to prescribe antibiotics and painkillers and postpone treatment; (2) to start the endodontic treatment and postpone the treatment by removing coronal pulp tissue only; (3) to start the endodontic treatment and postpone the treatment by placing a material like devitalizing/eugenol liquid on the pulp; (4) to start endodontic treatment and postpone the treatment by placing the antibacterial medicament in to the root canals; (5) to start endodontic treatment and complete the all treatment procedures; (6) tooth extraction; (7) follow-up.

To investigate the different approaches of endodontics specialists and $\mathrm{PhD}$ students to endodontic emergencies during the COVID-19 pandemic, an internet-based questionnaire was sent to 704 Turkish Endodontic Society members, and the results were evaluated. The participation rate was $28.8 \%$. Similar to other questionnaire-based studies performed during the COVID-19 outbreak, the ratio between female and male participants was not equal. ${ }^{19-22}$

According to the data obtained from the respondents, the most frequently treated endodontic diseases during the COVID-19 pandemic were "acute apical abscess (32.2\%)," "symptomatic irreversible pulpitis (30.8\%)," and "symptomatic apical periodontitis (26.8\%)." According to the findings of a recent study, ${ }^{14}$ which examined the characteristics of endodontic emergencies during the COVID-19 outbreak in Wuhan, the majority of endodontic emergency diagnoses are "symptomatic irreversible pulpitis (53.13\%)." Similar to the findings of Yu et al, ${ }^{14}$ in the current survey, the incidence of symptomatic irreversible pulpitis, symptomatic apical periodontitis, and acute apical abscess presented higher rates than other endodontic diseases.

Pain and swelling caused by pulpal infection constitute the majority of endodontic emergencies. The Turkish Ministry of Health Coronavirus Science Committee held on March 23, 2020, included endodontic diseases in the definition of "emergency practices in dentistry." ${ }^{23}$ In addition, the COVID-19 guidebook published by the Turkey Ministry of Health recommends that emergency dental treatments be performed and nonemergency practices postponed. ${ }^{17}$ The findings of this study coincided with this suggestion. Overall, the participants of this study preferred the following three treatment approaches for the seven selected cases: (1) prescribe antibiotics and/or painkillers and postpone the treatment, (2) follow-up, and (3) 
Table 5 Distribution of participants' responses to cases by education level

\begin{tabular}{|c|c|c|c|c|c|c|c|c|c|c|}
\hline & & $1(\%)$ & $2(\%)$ & $3(\%)$ & $4(\%)$ & $5(\%)$ & $6(\%)$ & 7 (\%) & $\chi 2^{\mathrm{a}}$ & $p$-Value \\
\hline \multirow[t]{2}{*}{ Case 1} & Endodontists & 40.9 & 6.3 & 2.4 & 22.8 & 20.5 & 0.0 & 7.1 & \multirow[t]{2}{*}{19.013} & \multirow[t]{2}{*}{$0.004^{\mathrm{a}}$} \\
\hline & $\begin{array}{l}\text { PhD students in } \\
\text { endodontics }\end{array}$ & 44.7 & 5.3 & 9.2 & 25.0 & 3.9 & 3.9 & 7.9 & & \\
\hline \multirow[t]{2}{*}{ Case 2} & Endodontists & 13.4 & 2.4 & 0.8 & 7.1 & 11.8 & 15.0 & 49.6 & \multirow[t]{2}{*}{4.388} & \multirow[t]{2}{*}{0.624} \\
\hline & $\begin{array}{l}\text { PhD students in } \\
\text { endodontics }\end{array}$ & 22.4 & 2.6 & 0.0 & 6.6 & 6.6 & 15.8 & 46.1 & & \\
\hline \multirow[t]{2}{*}{ Case 3} & Endodontists & 24.4 & 5.5 & 1.6 & 48.8 & 16.5 & 1.6 & 1.6 & \multirow[t]{2}{*}{7.646} & \multirow[t]{2}{*}{0.265} \\
\hline & $\begin{array}{l}\text { PhD students in } \\
\text { endodontics }\end{array}$ & 25.0 & 11.8 & 3.9 & 48.7 & 7.9 & 2.6 & 0.0 & & \\
\hline \multirow[t]{2}{*}{ Case4 } & Endodontists & 25.2 & 2.4 & 1.6 & 3.9 & 3.1 & 47.2 & 16.5 & \multirow[t]{2}{*}{10.73} & \multirow[t]{2}{*}{0.097} \\
\hline & $\begin{array}{l}\text { PhD students in } \\
\text { endodontics }\end{array}$ & 17.1 & 0.0 & 2.6 & 2.6 & 0.0 & 67.1 & 10.5 & & \\
\hline \multirow[t]{2}{*}{ Case 5} & Endodontists & 15.0 & 0.8 & 0.8 & 7.1 & 1.6 & 12.6 & 62.2 & \multirow[t]{2}{*}{5.563} & \multirow[t]{2}{*}{0.474} \\
\hline & $\begin{array}{l}\text { PhD students in } \\
\text { endodontics }\end{array}$ & 17.1 & 0.0 & 0.0 & 3.9 & 2.6 & 5.3 & 71.1 & & \\
\hline \multirow[t]{2}{*}{ Case 6} & Endodontists & 39.4 & 0.0 & 0.0 & 17.3 & 6.3 & 21.3 & 15.7 & \multirow[t]{2}{*}{8.186} & \multirow[t]{2}{*}{0.225} \\
\hline & $\begin{array}{l}\text { PhD students in } \\
\text { endodontics }\end{array}$ & 36.8 & 2.6 & 1.3 & 21.1 & 1.3 & 22.4 & 14.5 & & \\
\hline \multirow[t]{2}{*}{ Case 7} & Endodontists & 15.0 & 16.5 & 3.9 & 37.8 & 18.9 & 2.4 & 5.5 & \multirow[t]{2}{*}{4.169} & \multirow[t]{2}{*}{0.654} \\
\hline & $\begin{array}{l}\text { PhD students in } \\
\text { endodontics }\end{array}$ & 14.5 & 21.1 & 5.3 & 40.8 & 9.2 & 3.9 & 5.3 & & \\
\hline
\end{tabular}

${ }^{\mathrm{a}} \mathrm{p}<0.05$.

${ }^{b}$ Chi-square test. (1) to prescribe antibiotics and painkillers and postpone treatment; (2) to start the endodontic treatment and postpone the treatment by removing coronal pulp tissue only; (3) to start the endodontic treatment and postpone the treatment by placing a material like devitalizing/eugenol liquid on the pulp; (4) to start endodontic treatment and postpone the treatment by placing the antibacterial medicament in to the root canals; (5) to start endodontic treatment and complete the all treatment procedures; (6) tooth extraction; (7) follow-up.

start endodontic treatment but postpone the treatment by placing the antibacterial medicament into the root canals." These results are consistent with the recommendations given in a recent study for endodontic emergency treatments during the COVID-19 pandemic. ${ }^{10}$ However, the option to perform a full pulpotomy as recommended in the second management of "symptomatic irreversible pulpitis" and "symptomatic apical periodontitis" in that study $^{10}$ was less preferred by the respondents in the current study. The cases included in this survey were selected among real patients who presented to the Istanbul Medipol University Faculty of Dentistry clinics during the COVID-19 pandemic. The distribution of cases represents different endodontic diseases. According to the results for case 1 corresponding to "symptomatic apical periodontitis," the option to prescribe antibiotics and painkillers and postpone the treatment was the most frequently marked treatment approach (42.4\%). These results supported the study by Ather et $\mathrm{al}^{10}$ for the primary management of pain in "symptomatic apical periodontitis" and "symptomatic irreversible pulpitis." However, different from Ather et $\mathrm{al}^{10}{ }^{10}$ the most preferred treatment option for case 7 representing "symptomatic irreversible pulpitis" was to start endodontic treatment but postpone the treatment by placing the antibacterial medicament into the root canals (total pulpectomy; 39\%). However, the full pulpotomy method significantly shortens the duration of treatment and relieves the patient's acute symptoms quickly and effectively. ${ }^{24}$ Thus, a full pulpotomy is suitable for reducing the risk of spreading COVID-19 than a total pulpectomy and for effectively eliminating the patient's acute symptoms. While the recommended method for the primary management of acute apical abscess during the COVID-19 pandemic was drainage and pharmacologic therapy, ${ }^{10}$ the results of case 3 showed that "starting endodontic and postponing the treatment by placing antibacterial medicament into the root canals" was the preferred method, referred to as "acute apical abscess" in the present study. While it is possible to agree with the recommendation of Ather et $\mathrm{al}^{10}$ in cases where an acute abscess can be managed with drainage and medical drug use, it may be better to adopt the full pulpectomy approach during the COVID-19 pandemic in cases where abscess drainage is not possible or when the disease recurs. For cases 5 and 6, the respective treatment approaches preferred for retreatment were to follow-up (65.5\%) and prescribe antibiotics and/or painkillers and postpone the treatment (38.4\%). The participants chose different treatment approaches because case 6 is symptomatic. Possible reasons for postponing retreatment in cases 5 and 6 include a lower chance of success compared with primary root canal treatment, prolonged treatment procedures, repeated visits to the clinic, and complicating the treatment process. ${ }^{25}$ Finally, for case 2 , which represents "chronic apical periodontitis," the 
Table 6 Distribution of participants' responses to cases by working place

\begin{tabular}{|c|c|c|c|c|c|c|c|c|c|c|}
\hline & & $1(\%)$ & $2(\%)$ & $3(\%)$ & $4(\%)$ & $5(\%)$ & $6(\%)$ & $7(\%)$ & $\chi 2^{\mathrm{a}}$ & $p$-Value \\
\hline \multirow[t]{3}{*}{ Case 1} & University clinics & 46.4 & 5.8 & 5.8 & 22.5 & 8.0 & 2.2 & 9.4 & \multirow[t]{3}{*}{31.495} & \multirow[t]{3}{*}{0.002} \\
\hline & Private clinics & 23.3 & 7.0 & 4.7 & 23.3 & 37.2 & 0.0 & 4.7 & & \\
\hline & Public clinics & 54.5 & 4.5 & 0.0 & 31.8 & 9.1 & 0.0 & 0.0 & & \\
\hline \multirow[t]{3}{*}{ Case 2} & University clinics & 18.1 & 2.9 & 0.7 & 8.0 & 7.2 & 15.2 & 47.8 & \multirow[t]{3}{*}{11.471} & \multirow[t]{3}{*}{0.489} \\
\hline & Private clinics & 16.3 & 0.0 & 0.0 & 4.7 & 20.9 & 14.0 & 44.2 & & \\
\hline & Public clinics & 9.1 & 4.5 & 0.0 & 4.5 & 4.5 & 18.2 & 59.1 & & \\
\hline \multirow[t]{3}{*}{ Case 3} & University clinics & 25.4 & 9.4 & 3.6 & 50.0 & 8.0 & 2.2 & 1.4 & \multirow[t]{3}{*}{28.196} & \multirow[t]{3}{*}{0.005} \\
\hline & Private clinics & 16.3 & 4.7 & 0.0 & 44.2 & 34.9 & 0.0 & 0.0 & & \\
\hline & Public clinics & 36.4 & 4.5 & 0.0 & 50.0 & 4.5 & 4.5 & 0.0 & & \\
\hline \multirow[t]{3}{*}{ Case 4} & University clinics & 19.6 & 0.7 & 2.2 & 4.3 & 0.7 & 57.2 & 15.2 & \multirow[t]{3}{*}{16.985} & \multirow[t]{3}{*}{0.15} \\
\hline & Private clinics & 23.3 & 4.7 & 0.0 & 2.3 & 7.0 & 51.2 & 11.6 & & \\
\hline & Public clinics & 36.4 & 0.0 & 4.5 & 0.0 & 0.0 & 45.5 & 13.6 & & \\
\hline \multirow[t]{3}{*}{ Case 5} & University clinics & 15.9 & 0.0 & 0.0 & 1.4 & 2.2 & 9.4 & 71.0 & \multirow[t]{3}{*}{34.413} & \multirow[t]{3}{*}{0.001} \\
\hline & Private clinics & 9.3 & 2.3 & 0.0 & 18.6 & 2.3 & 11.6 & 55.8 & & \\
\hline & Public clinics & 27.3 & 0.0 & 4.5 & 9.1 & 0.0 & 9.1 & 50.0 & & \\
\hline \multirow[t]{3}{*}{ Case 6} & University clinics & 35.5 & 1.4 & 0.7 & 18.1 & 2.2 & 25.4 & 16.7 & \multirow[t]{3}{*}{20.106} & \multirow[t]{3}{*}{0.065} \\
\hline & Private clinics & 37.2 & 0.0 & 0.0 & 23.3 & 14.0 & 11.6 & 14.0 & & \\
\hline & Public clinics & 59.1 & 0.0 & 0.0 & 13.6 & 0.0 & 18.2 & 9.1 & & \\
\hline \multirow[t]{3}{*}{ Case 7} & University clinics & 15.9 & 19.6 & 3.6 & 37.0 & 11.6 & 4.3 & 8.0 & \multirow[t]{3}{*}{23.829} & \multirow[t]{3}{*}{0.021} \\
\hline & Private clinics & 9.3 & 16.3 & 9.3 & 34.9 & 30.2 & 0.0 & 0.0 & & \\
\hline & Public clinics & 18.2 & 13.6 & 0.0 & 59.1 & 9.1 & 0.0 & 0.0 & & \\
\hline
\end{tabular}

${ }^{\mathrm{a}} \mathrm{p}<0.05$.

${ }^{b}$ Chi-square test. (1) to prescribe antibiotics and painkillers and postpone treatment; (2) to start the endodontic treatment and postpone the treatment by removing coronal pulp tissue only; (3) to start the endodontic treatment and postpone the treatment by placing a material like devitalizing/eugenol liquid on the pulp; (4) to start endodontic treatment and postpone the treatment by placing the antibacterial medicament in to the root canals; (5) to start endodontic treatment and complete the all treatment procedures; (6) tooth extraction; (7) follow-up.

respondents preferred the follow-up option (48.3\%), most likely because of the absence of pain or history of periapical swelling. This result is a suitable approach to case 2 to reduce the risk of spreading COVID-19 and to avoid endangering the patient's health for a nonemergency dental treatment. For case $4,54.7 \%$ of the participants opted to extract the third molar tooth. This preference may relate to the possibility of complications occurring during the endodontic treatment of third molar teeth, difficulty accessing the tooth, the possibility of encountering an abnormal root canal structure, and differences in the eruption pattern. If adjacent teeth are present in the mouth and are intact, it may be possible to extract these teeth. However, the positive aspects of this approach include that these teeth do not require a prosthetic restoration following the extraction and thus effectively eliminate the endodontic emergency. Depending on the characteristics of the case and the dental professional's experience, minimally invasive dental treatments (MIDT) may be recommended in cases with such profound caries with no signs of periapical infection and intact coronal integrity. MIDT for deep dentin caries are conservative techniques that preserve the tooth structure as much as possible and prevent irreversible pulp damage. These techniques, which include atraumatic restorative treatment (ART) and selective caries tissue removal (e.g., indirect pulp capping, stepwise removal, and selective removal to soft dentine), ${ }^{26}$ are valuable during the COVID-19 pandemic because they reduce aerosol formation in the environment and minimize the need for endodontic treatment and subsequent prosthetic rehabilitation, thus lowering the risk of transmission. Among these treatments, ART is an MIDT method that is supported by scientific evidence, limits the removal of natural tooth structure, has a positive effect on the patient's quality of life, and is cost effective..$^{26,27}$ In the profound caries lesions extending into the pulpal third or quarter of the dentine radiographically, selective removal to soft dentine or stepwise removal with the advantage of not requiring a second visit may also be an appropriate treatment option. ${ }^{26,28}$ In cases that require root canal treatment, treatment should be completed as soon as possible and in a single session without sacrificing quality, thus reducing exposure of the patient and the dental team to the virus during treatment and preventing the spread of the disease due to repeated sessions. The use of a rubber dam during endodontic treatment is important for reducing aerosol formation significantly. In addition, working with a dental loop or an operation microscope is preferred because it allows the patient to work at a certain distance and also facilitates the dentist's work in solving some complex 
clinical problems that were previously not possible without the help of magnifying devices. ${ }^{29}$

\section{Conclusion}

In conclusion, deep carious teeth should be treated with minimally invasive methods as much as possible, and the treatment should be delayed by eliminating the patient's acute symptoms during the pandemic process for teeth that require root canal treatment. In the postpandemic process, it should be aimed to complete the treatment in a single session and optimum time taking the necessary precautions in a safe environment.

\section{Note}

The results of this study were presented as a poster presentation at IAPD20 Virtual on September 13-17, 2020.

\section{Ethical Approval}

Ethical approval of the study design was obtained from the institutional review board of Istanbul Medipol University (approval number:10840098-604.01.01-E.14696/326) and Ministry of Health of Turkey. Verbal consent was obtained from the patients whose radiographs were used for reference in the study. Additionally, all procedures performed in studies involving human participants were in accordance with the ethical standards of the institutional and/or national research committee and with the 1964 Helsinki declaration and its later amendments or comparable ethical standards.

\section{Authors' Contributions}

K.O.: conceptualization, methodology, software data curation, preparing the original draft; S.I.Y.: methodology, visualization, investigation, reviewing and editing the manuscript.

\section{Funding}

None.

\section{Conflict of Interest}

None declared.

\section{Acknowledgments}

The authors would like to thank Hatice Karakaş for her assistance in the statistical analysis.

\section{References}

1 World Health Organization. Pneumonia of cause-China. Available at: https://www.who.int/csr/don/05-january-2020-pneumonia-of-unkown-cause-china/en/. Accessed March 12, 2021

2 Zhu N, Zhang D, Wang W, et al; China Novel Coronavirus Investigating and Research Team. A novel coronavirus from patients with pneumonia in China, 2019. N Engl J Med 2020;382(8):727-733

3 Chan JF, Yuan S, Kok KH, et al. A familial cluster of pneumonia associated with the 2019 novel coronavirus indicating person-to-person transmission: a study of a family cluster. Lancet 2020;395(10223):514-523

4 Peng X, Xu X, Li Y, Cheng L, Zhou X, Ren B. Transmission routes of 2019-nCoV and controls in dental practice. Int J Oral Sci 2020;12(1):9
5 To KK, Tsang OT, Yip CC, et al. Consistent detection of 2019 novel coronavirus in saliva. Clin Infect Dis 2020;71(15):841-843

6 Zou X, Chen K, Zou J, Han P, Hao J, Han Z. Single-cell RNA-seq data analysis on the receptor ACE2 expression reveals the potential risk of different human organs vulnerable to 2019-nCoV infection. Front Med 2020;14(2):185-192

$7 \mathrm{Xu} \mathrm{H}$, Zhong L, Deng J, et al. High expression of ACE2 receptor of 2019-nCoV on the epithelial cells of oral mucosa. Int J Oral Sci 2020;12(1):8

8 Coulthard P. Dentistry and coronavirus (COVID-19) - moral decision-making. Br Dent J 2020;228(7):503-505

9 Backer JA, Klinkenberg D, Wallinga J. Incubation period of 2019 novel coronavirus (2019-nCoV) infections among travellers from Wuhan, China, 20-28 January 2020. Euro Surveill 2020;25(5):2000062

10 Ather A, Patel B, Ruparel NB, Diogenes A, Hargreaves KM. Coronavirus disease 19 (COVID-19): implications for clinical dental care. J Endod 2020;46(5):584-595

11 Guan WJ, Ni ZY, Hu Y, et al; China Medical Treatment Expert Group for Covid-19. Clinical characteristics of coronavirus disease 2019 in China. N Engl J Med 2020;382(18):1708-1720

12 Rothe C, Schunk M, Sothmann P, et al. Transmission of 2019-nCoV infection from an asymptomatic contact in Germany. N Engl J Med 2020;382(10):970-971

13 Huang SM, Huang JY, Yu HC, Su NY, Chang YC. Trends, demographics, and conditions of emergency dental visits in Taiwan 1997-2013: A nationwide population-based retrospective study. J Formos Med Assoc 2019;118(2):582-587

14 Yu J, Zhang T, Zhao D, Haapasalo M, Shen Y. Characteristics of Endodontic Emergencies during Coronavirus Disease 2019 Outbreak in Wuhan. J Endod 2020;46(6):730-735

15 Alharbi A, Alharbi S, Alqaidi S. Guidelines for dental care provision during the COVID-19 pandemic. Saudi Dent J 2020;32(4):181-186

16 van Doremalen N, Bushmaker T, Morris DH, et al. Aerosol and surface stability of SARS-CoV-2 as compared with SARS-CoV-1. N Engl J Med 2020;382(16):1564-1567

17 Turkish Ministry of Health Guideline. COVID-19 Rehberi. T.C. Sağlık Bakanlığı Halk Sağlığı Genel Müdürlüğü. Bilim Kurulu Çalışması. Ankara. Available at: https://covid19.saglik.gov.tr/ TR-66337/genel-bilgiler-epidemiyoloji-ve-tani.html Accessed March 12, 2021

18 Turkish Ministry of Health Guideline. COVID-19 Pandemisinde Normalleşme Döneminde Sağlık Kurumlarında Çalışma Rehberi. Available at: https://covid19.saglik.gov.tr/TR-66532/ saglik-kurumlarinda-calisma-rehberi-ve-enfeksiyon-kontrol-onlemleri.html. Accessed March 12, 2021

19 Modi PD, Nair G, Uppe A, et al. COVID-19 awareness among healthcare students and professionals in mumbai metropolitan region: a questionnaire-based survey. Cureus 2020;12(4):e7514

20 Ahmed MA, Jouhar R, Ahmed N, et al. Fear and practice modifications among dentists to combat novel coronavirus disease (COVID-19) outbreak. Int J Environ Res Public Health 2020;17(8):2821

21 Duruk G, Gümüşboğa ZS, Çolak C. Investigation of Turkish dentists' clinical attitudes and behaviors towards the COVID-19 pandemic: a survey study. Braz Oral Res 2020;34:e054

22 Khader Y, Al Nsour M, Al-Batayneh OB, et al. Dentists' Awareness, Perception, and Attitude Regarding COVID-19 and Infection Control: Cross-Sectional Study Among Jordanian Dentists. JMIR Public Health Surveill 2020;6(2):e18798

23 Turkish Dental Association. Diş Hekimliğinde Acil Uygulamalar. Sağlık Kurumlarına Yönelik Alınacak Uygulamaların Belirlenmesi. Available at: http://www.tdb.org.tr/icerik_ goster.php?Id=3427. Accessed March 12, 2021 
24 Eren B, Onay EO, Ungor M. Assessment of alternative emergency treatments for symptomatic irreversible pulpitis: a randomized clinical trial. Int Endod J 2018;51(suppl 3):e227-e237

$25 \mathrm{Ng}$ YL, Mann V, Gulabivala K. Outcome of secondary root canal treatment: a systematic review of the literature. Int Endod J 2008;41(12):1026-1046

26 Giacaman RA, Muñoz-Sandoval C, Neuhaus KW, Fontana M, Chałas R. Evidence-based strategies for the minimally invasive treatment of carious lesions: review of the literature. Adv Clin Exp Med 2018;27(7):1009-1016
27 Allen PF, Da Mata C, Hayes M. Minimal intervention dentistry for partially dentate older adults. Gerodontology 2019;36(2):92-98

28 Banerjee A, Frencken JE, Schwendicke F, Innes NPT. Contemporary operative caries management: consensus recommendations on minimally invasive caries removal. Br Dent J 2017;223(3):215-222

29 Mallikarjun SA, Devi PR, Naik AR, Tiwari S. Magnification in dental practice: how useful is it? J Health Res Rev 2015;2:39-44 